\title{
Characterization of the Bonding Zone in AZ91/AISi12 Bimetals Fabricated by Liquid-Solid Compound Casting Using Unmodified and Thermally Modified AISi12 Alloy
}

\author{
Renata Mola - Tomasz Bucki* \\ Kielce University of Technology, Faculty of Mechatronics and Mechanical Engineering, Poland
}

Liquid-solid compound casting was used to produce two types of AZ91/AISi12 joints. The magnesium alloy was the cast material poured onto a solid aluminium alloy insert with an unmodified or modified structure. The bonding zone obtained for the unmodified insert was not uniform in thickness. There was a eutectic region $\left(\mathrm{Mg}_{17} \mathrm{Al} \mathrm{I}_{12}+\right.$ a solid solution of $\mathrm{Al}$ in $\left.\mathrm{Mg}\right)$ in the area closest to the $\mathrm{AZ91}$. The region adjacent to the AlSi12 had a non-uniform structure with partly reacted Si particles surrounded by the $\mathrm{Mg}_{2} \mathrm{Si}$ phase and agglomerates of $\mathrm{Mg}_{2} \mathrm{Si}$ particles unevenly distributed in the Mg-Al intermetallic phases matrix. Cracks were detected in this region. In the AZ91/AISi12 joint produced with a thermally modified AISi12 insert, the bonding zone was uniform in thickness. The region closest to the AZ91 alloy also had a eutectic structure. However, significant microstructural changes were reported in the region adjacent to the modified AISi12 alloy. The microstructure of the region was uniform with no cracks; the fine $\mathrm{Mg}_{2} \mathrm{Si}$ particles were evenly distributed over the Mg-Al intermetallic phase matrix. The study revealed that in both cases the microhardness of the bonding zone was several times higher than those of the individual alloys; however, during indenter loading, the bonding zone fabricated from modified AISi12 alloy was less prone to cracking.

Keywords: compound casting, magnesium alloy, aluminium alloy, grain refinement, microstructure, microhardness

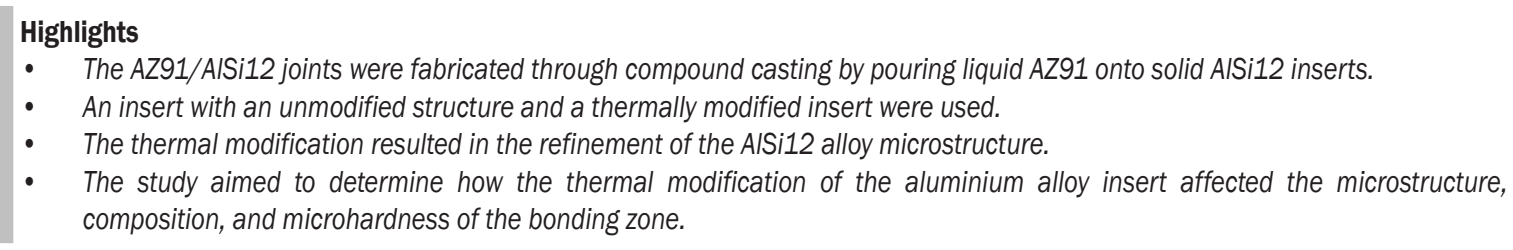

\section{INTRODUCTION}

Compound casting is an inexpensive and efficient method for joining two dissimilar metals or alloys to produce bimetallic parts, often complex in shape, with no geometric or dimensional restraints. The literature on the topic shows that compound casting has been used for years to connect various dissimilar alloys, e.g., steel and cast iron [1] to [4], steel and alloyed steel [5] and [6], steel and $\mathrm{Al}[7]$ and [8], $\mathrm{Al}$ and $\mathrm{Cu}$ [9], dissimilar Al alloys [10] and [11], dissimilar $\mathrm{Mg}$ alloys [12] or $\mathrm{Al}$ and $\mathrm{Mg}$ alloys [13] to [27]. There are two variants of the method: liquid-solid compound casting and liquid-liquid compound casting, with the former being more common. Liquid-solid compound casting consists of pouring one liquid alloy directly onto a solid insert made of another alloy, placed in a mould cavity. Liquid-liquid compound casting [5], [11] and [22], in contrast, involves pouring two molten alloys together directly into a mould. To prevent their mixing, a thin plate made of still another alloy is placed in the mould to act as an interlayer [22]. An alternative solution is to rapidly cool one of the liquid alloys at the joint interface so that it starts to solidify when in contact with the other alloy poured [11].
Currently, magnesium and aluminium alloys are widely used in the automotive and aviation industries [28] to [30] as the application of lightweight materials aids in reducing the vehicle mass and, consequently, fuel consumption. A bimetal based on the two alloys retains the favourable properties of both and, as such, is an extremely attractive engineering material. $\mathrm{Mg} / \mathrm{Al}$ bimetals can be obtained using various methods [31]. As stated above, research on the joining of $\mathrm{Mg}$ alloys to $\mathrm{Al}$ alloys using compound casting has been conducted extensively in recent years. Some studies have investigated joining pure $\mathrm{Mg}$ to pure $\mathrm{Al}$ [14], [17] and [24]. In this case, three zones can be differentiated at the interface: a eutectic $\left(\mathrm{Mg}_{17} \mathrm{Al}_{12}\right.$ + a solid solution of $\mathrm{Al}$ in $\mathrm{Mg}$ ) adjacent to the $\mathrm{Mg}$, the $\mathrm{Mg}_{17} \mathrm{Al}_{12}$ intermetallic phase in the middle and the $\mathrm{Al}_{3} \mathrm{Mg}_{2}$ intermetallic phase close to the $\mathrm{Al}$. Some works dealing with $\mathrm{Al} / \mathrm{Mg}$ bimetals produced by compound casting reveal that good results are obtained when $\mathrm{Mg}$ is poured onto an $\mathrm{Al}$ insert [14] and [17]. The developments in $\mathrm{Mg} / \mathrm{Al}$ compound casting indicate that a reaction can occur between liquid $\mathrm{Mg}$ and the oxide film on the surface of an $\mathrm{Al}$ insert. As the reaction leads to the removal of the passive film, there is direct contact between the metals, which allows the 
joint to be formed. The use of molten $\mathrm{Al}$ and solid $\mathrm{Mg}$ [14], however, results in the occurrence of gaps at the interface; this is related to the presence of unreactive oxides on the surface of an $\mathrm{Mg}$ insert. One study on the subject [24] suggests that it is possible to form a uniform bonding zone for $\mathrm{Al} / \mathrm{Mg}$ rods produced by pouring $\mathrm{Al}$ around an $\mathrm{Mg}$ insert. The major problem encountered during the fabrication of $\mathrm{Mg} / \mathrm{Al}$ bimetal joints is the occurrence of $\mathrm{Mg}-\mathrm{Al}$ intermetallic phases at the interface. It is commonly known that $\mathrm{Mg}-\mathrm{Al}$ intermetallic phases are hard but brittle. Thus, when a continuous zone of these phases forms close to the Al-based insert, the joint strength is low (20.2 MPa to 39.9 MPa) [14]. For this reason, structure modification to improve the strength properties of a bimetallic joint seems a promising approach. Previous research has included studies of compound casting applied to join $\mathrm{Mg}$ alloys to $\mathrm{Al}$ alloys, e.g., $\mathrm{Mg} / \mathrm{AlMg} 1$ [13], $\mathrm{Mg} /$ A413 [15], AM50/A319 [16], AZ91/A356 [18] and [22], AZ91/AlSi17 [19] and [20], ZE41/AlSi12 [21], AZ31/AlZn (AlZn6, AlZn15, AlZn30) [23], and AZ31/ AW-6060 [25]. The experimental data presented in the above-mentioned works show that the microstructure of the bonding zone undergoes modification because of the presence of other alloying elements in the alloys joined. As pointed out in [15] and [19] to [21], the use of AlSi alloy in the form of a solid insert leads to the formation of the $\mathrm{Mg}-\mathrm{Al}$ intermetallic phases as well as the $\mathrm{Mg}_{2} \mathrm{Si}$ phase in the bonding zone close to the $\mathrm{Al}$ alloy. Applying ZE41 magnesium alloy [21] also results in some modification of the bonding zone structure in the area close to the $\mathrm{Mg}$ alloy. The Mg-Zn-RE and Al-RE intermetallic phases are detected there. The use of $\mathrm{Al}$ alloys containing a high amount of $\mathrm{Zn} \mathrm{[23]}$ causes a change in the morphology and microstructure of the interface, where Zn-rich intermetallic phases are predominant. As noted in [13], [22], [26] and [27], significant modification of the bonding zone structure

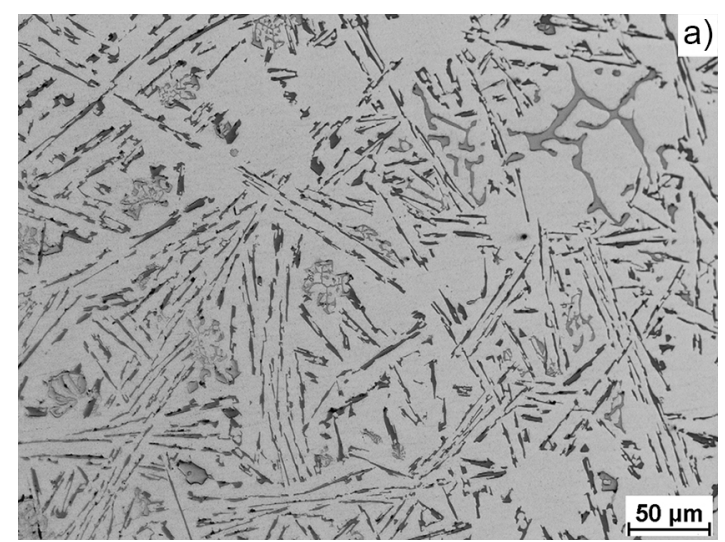

can also be achieved by applying an interlayer made of a different metal: $\mathrm{Mn}$ [13], $\mathrm{Zn} \mathrm{[22]} \mathrm{and} \mathrm{[26]} \mathrm{and} \mathrm{Ni}$ [27] between $\mathrm{Mg}$ and $\mathrm{Al}$ in compound casting. The research described in [13] shows that an Mn interlayer prevents $\mathrm{Mg}-\mathrm{Al}$ intermetallic phases from forming at the $\mathrm{Mg} / \mathrm{Al}$ interface. The results presented in [22] and [26] indicate that the bonding zone of the AZ31/AW6060 joint fabricated with a $\mathrm{Zn}$ interlayer is mainly composed of $\mathrm{Mg}-\mathrm{Al}-\mathrm{Zn}$ phases and it is characterized by high shear strength, higher than that obtained without the $\mathrm{Zn}$ interlayer [26]. Li et al. [27] reported that the application of a $\mathrm{Ni}$ interlayer could also limit the formation of brittle $\mathrm{Mg}$-Al intermetallic phases and improve the strength of the joint.

This article focuses on the fabrication of a light bimetallic material, composed of AZ91 magnesium alloy and AlSi12 aluminium alloy, using the liquidsolid compound casting method. The present study aimed to investigate how the thermal modification process of the aluminium alloy insert would affect the microstructure, composition, and microhardness of the bonding zone formed between the alloys joined.

\section{EXPERIMENTAL DETAILS}

AZ91 magnesium alloy, containing $9.14 \mathrm{wt} \% \mathrm{Al}$, $0.64 \mathrm{wt} \% \mathrm{Zn}$ and $0.23 \mathrm{wt} \% \mathrm{Mn}$, was used as the cast material. Two types of AlSi12 aluminium alloy (10.97 wt $\% \mathrm{Si}, 0.43$ wt $\% \mathrm{Mn}, 0.26 \mathrm{wt} \% \mathrm{Fe}, 0.15 \mathrm{wt} \% \mathrm{Mg}$ and $0.15 \mathrm{wt} \% \mathrm{Cu}$ ) were considered: unmodified (asreceived) and thermally modified. AlSi12 was in the form of cylindrical inserts $30 \mathrm{~mm}$ in diameter and $10 \mathrm{~mm}$ in thickness. The unmodified inserts were cut from an AlSi12 ingot. The thermally modified inserts were prepared by pouring AlSi12 alloy onto a thick steel plate. The microstructures of both insert types are shown in Fig. 1. The thermal modification caused significant refinement of the AlSi12 alloy

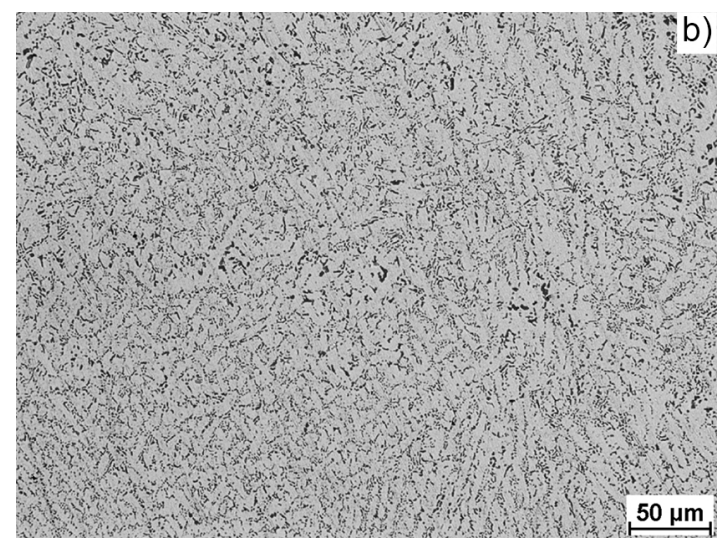

Fig. 1. OM images of the AISi12 inserts; a) unmodified; b) modified 
microstructure, as depicted in Fig. 1b. Before compound casting, the surfaces of the $\mathrm{Al}$ alloy inserts were ground using $\mathrm{SiC}$ papers up to 800 grit, polished and cleaned with ethanol. The liquid-solid compound casting process proceeded as follows. First, an insert was placed in the cavity of a steel mould. Then, both were preheated to $300{ }^{\circ} \mathrm{C}$. No protective atmosphere was used because of the ability of the molten $\mathrm{Mg}$ alloy to react with the oxide film on the surface of the $\mathrm{Al}$ alloy.

Next, the AZ91 alloy (100 g) was melted in a furnace under an argon atmosphere at a temperature of $660{ }^{\circ} \mathrm{C}$. Finally, the $\mathrm{Mg}$ alloy was poured under normal atmospheric conditions into the mould with the aluminium alloy insert inside.

The microstructural analysis of the AZ91/AlSi12 joints was performed on cross-sections prepared using standard metallographic techniques, with the final polishing being carried out with aluminium oxide slurry $(0.3 \mu \mathrm{m})$. A Nikon ECLIPSE MA200 optical microscope (OM) and a JEOL JSM-5400 scanning electron microscope (SEM), equipped with an energydispersive X-ray spectrometer (EDS), were employed for the examinations. The microhardness of the bonding zone was measured with a MATSUZAWA MMT Vickers tester at a load of $100 \mathrm{~g}$.

\section{RESULTS AND DISCUSSION}

Fig. 2 shows low and high magnification OM images of the microstructure of the AZ91/AlSi12 bimetal joint produced with an unmodified AlSi12 insert. It is visible that the bonding zone is continuous but nonuniform in thickness $(120 \mu \mathrm{m}$ to $200 \mu \mathrm{m})$ or structure. The area of the bonding zone close to the AZ91 alloy is thinner and darker, while that close to the AlSil2 is thicker with fine and coarse particles unevenly distributed in the light matrix. The contour of the interface with the AlSi12 alloy is highly irregular in shape (Fig. 2b).

Fig. 3 shows details of the microstructure of the bonding zone observed through scanning electron microscopy. The results of the EDS quantitative analysis conducted at points 1 to 11 , as marked in this figure, are provided in Table 1. The high magnification image in Fig. 3a reveals that the darker region adjacent to the AZ91 has a structure with two phases: dark and light (points 1 and 2, respectively). The Al-Mg equilibrium phase diagram [32] and the EDS results suggest that the chemical composition of the dark phase corresponds to a solid solution of $\mathrm{Al}$ in $\mathrm{Mg}$, whereas the light phase is the $\mathrm{Mg}_{17} \mathrm{Al}_{12}$ intermetallic phase. Below the eutectic, there are light dendrites (point 3) of the $\mathrm{Mg}_{17} \mathrm{Al}_{12}$ phase. Fig. $3 \mathrm{~b}$ depicts the region adjacent to the AlSi12 alloy. The chemical composition of the light matrix is not uniform. The $\mathrm{Mg}_{17} \mathrm{Al}_{12}$ intermetallic phase was detected in the matrix close to the eutectic (point 4), and the $\mathrm{Al}_{3} \mathrm{Mg}_{2}$ phase (point 5) was observed close to the AlSi12.

As can be seen from Fig. 1a, the microstructure of the unmodified AlSi12 alloy comprised needle-like eutectic Si and Chinese script-like phases distributed regularly in the Al matrix. The Chinese script-like AlSi-Mn-Fe phases (point 6), as well as the needle-like and irregularly shaped Si particles (points 7 and 8, respectively), were also present in the bonding zone (Fig. 3b). The Al-Si-Mn-Fe phases were stable; they did not undergo transformation through reactions at the interface, so their Chinese script-like shape remained unchanged.
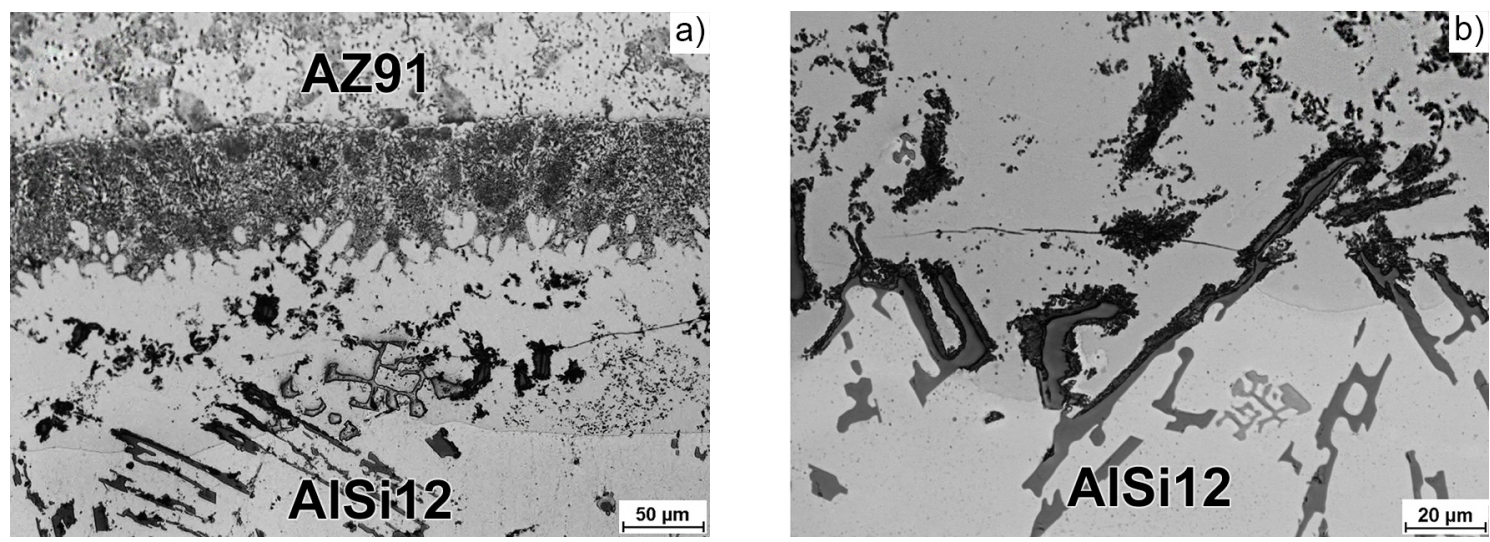

Fig. 2. OM images of the bonding zone microstructure for the bimetallic joint with an unmodified AlSi12 insert; a) low magnification; b) high magnification 

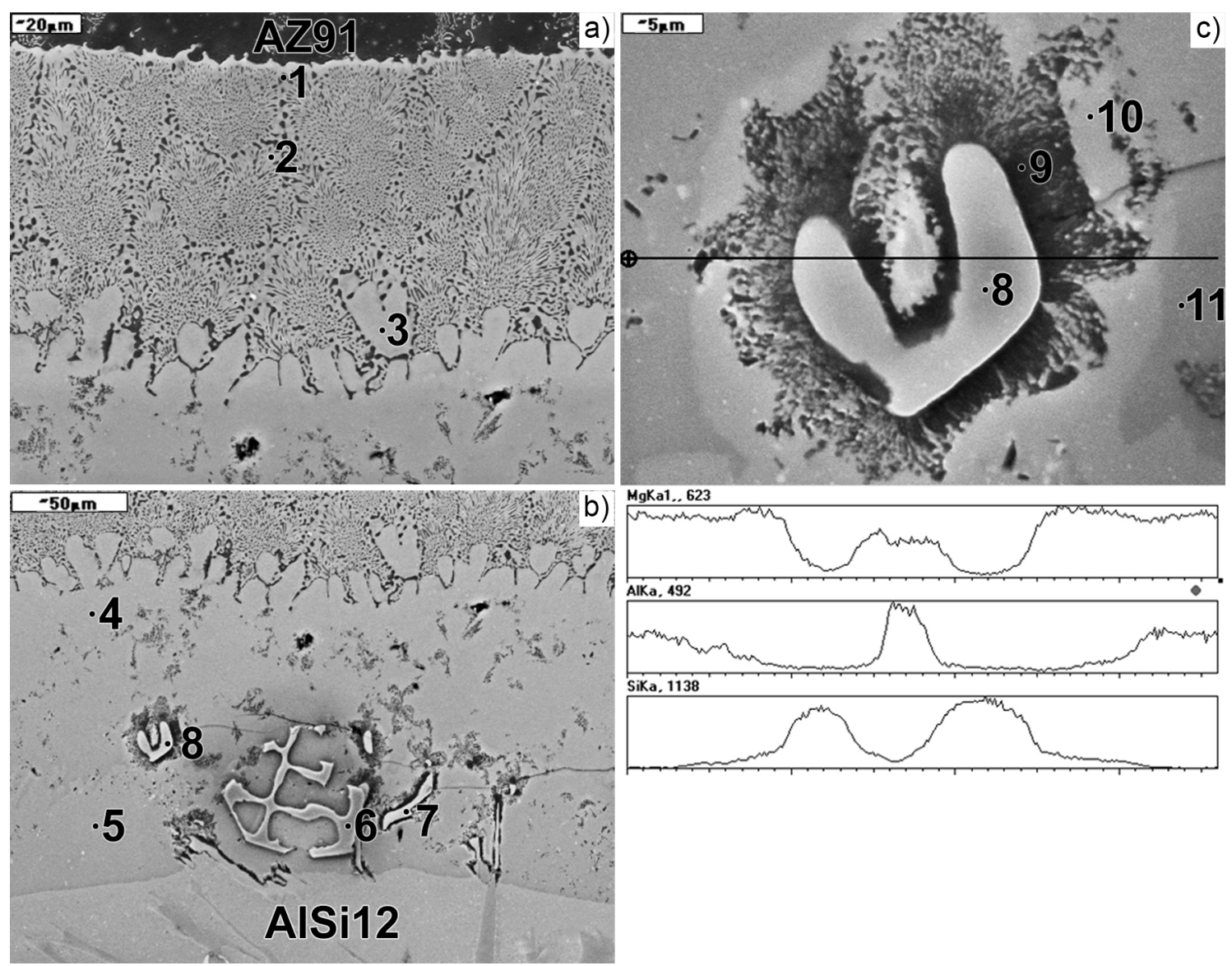

Fig. 3. SEM images of the bonding zone for the bimetallic joint with the unmodified AISi12; a) close to the AZ91;

b) close to the AISi12; c) details of the zone close to the AISi12 and the corresponding EDS line scan results

Table 1. Results of the EDS quantitative analysis at points marked in Fig. 3

\begin{tabular}{ccccccc}
\hline \multirow{2}{*}{ Point } & $\mathrm{Mg}$ & $\mathrm{Al}$ & $\mathrm{Zn}$ & $\mathrm{Si}$ & $\mathrm{Mn}$ & $\mathrm{Fe}$ \\
\cline { 2 - 7 } & \multicolumn{7}{c}{ [at.\%] } \\
\hline 1 & 84.15 & 15.85 & - & - & - & - \\
\hline 2 & 64.36 & 35.42 & 0.22 & - & - & - \\
\hline 3 & 63.08 & 36.92 & - & - & - & - \\
\hline 4 & 62.76 & 37.24 & - & - & - & - \\
\hline 5 & 41.76 & 58.24 & - & - & - & - \\
\hline 6 & 1.64 & 69.13 & - & 13.28 & 8.17 & 7.78 \\
\hline 7 & - & 0.56 & - & 99.44 & - & - \\
\hline 8 & - & 0.44 & - & 99.56 & - & - \\
\hline 9 & 62.86 & 4.77 & - & 32.37 & - & - \\
\hline 10 & 39.49 & 60.51 & - & - & - & - \\
\hline 11 & 55.75 & 44.25 & - & - & - & - \\
\hline
\end{tabular}

It was found that the Si particles observed in the bonding zone were surrounded by a darker phase. At a certain distance from the $\mathrm{Si}$ particles, the darker phase was fragmented and dispersed in the lightcoloured matrix. This phenomenon is clearly visible in Fig. 3c. The EDS linear analysis along the marked line reveals that the darker phase area is rich in $\mathrm{Mg}$ and $\mathrm{Si}$. According to the Mg-Si binary phase diagram [33], the solubility of $\mathrm{Si}$ in $\mathrm{Mg}$ is extremely low, and $\mathrm{Si}$ atoms react with $\mathrm{Mg}$ atoms and form the $\mathrm{Mg}_{2} \mathrm{Si}$ phase. The results of the EDS quantitative analysis in this area (point 9) confirm the presence of the $\mathrm{Mg}_{2} \mathrm{Si}$ phase. Some of the Si particles are too large to be fully consumed in the reaction with $\mathrm{Mg}$ during compound casting. Locally in the bonding zone, there are single $\mathrm{Mg}_{2} \mathrm{Si}$ particles and their agglomerates, where smaller $\mathrm{Si}$ particles were fully consumed. The light matrix area close to the $\mathrm{Mg}_{2} \mathrm{Si}$ "halo" is slightly lighter in colour (point 10), and its chemical composition resembles that of the $\mathrm{Al}_{3} \mathrm{Mg}_{2}$ intermetallic phase. In the slightly darker area (point 11) surrounding the $\mathrm{Al}_{3} \mathrm{Mg}_{2}$ particles, the atomic percentage of $\mathrm{Mg}$ is higher and more similar to that of the $\mathrm{Mg}_{17} \mathrm{Al}_{12}$ intermetallic phase. The decrease in the $\mathrm{Mg}$ content in the light matrix close to the dark halo resulted from the formation of the $\mathrm{Mg}_{2} \mathrm{Si}$ phase. Figs. 2a, b and Figs. 

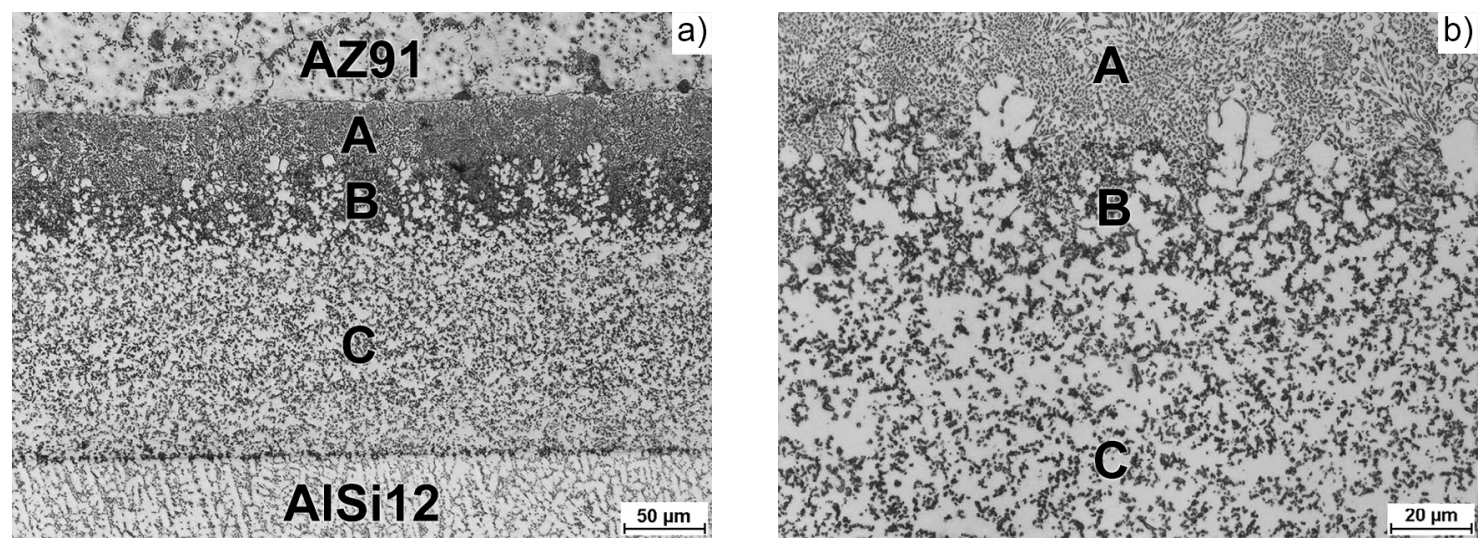

Fig. 4. OM image of the microstructure of the bonding zone between AZ91 and modified AISi12;

a) lower magnification; b) higher magnification

$3 \mathrm{a}$ and $\mathrm{b}$ reveal some pores and cracks in the bonding zone. The defects were caused by volume changes associated with the phase transformation at the reactive interface during liquid-solid compound casting. Long parallel cracks can be seen propagating across the light matrix between areas where the transformation of large Si particles into the $\mathrm{Mg}_{2} \mathrm{Si}$ phase occurred. The volume changes accompanying the formation of new phases resulted in transformation stresses, which occurred locally and initiated the formation of cracks in the matrix composed of brittle $\mathrm{Mg}$ - $\mathrm{Al}$ intermetallic phases. It is evident that the presence of numerous defects, such as cracks and pores, as well as residual stress negatively affects the properties of the joint. The microstructural observations also showed that the contour of the interface between the bonding zone and the AlSi12 alloy was highly irregular. The long needles of Si present in the AlSi12 alloy disturbed the diffusion reactions between the AZ91 and the AlSi12, which resulted in a non-uniform thickness of the bonding zone.

The OM images in Fig. 4 show the microstructure of the bonding zone obtained when a thermally modified AlSi12 insert was used. From the low magnification view in Fig. $4 \mathrm{a}$, it is evident that the refinement of the insert microstructure led to substantial changes in the joint microstructure. In this case, the bonding zone has a uniform thickness of about $250 \mu \mathrm{m}$. The interface between the AZ91 alloy and the bonding zone and that between the bonding zone and the AlSi12 alloy are flat. The region of the bonding zone adjacent to the AZ91 alloy is thinner and darker than the region close to the AlSi12, as was the case with the joint fabricated with an unmodified AlSi12 insert. The thinner and darker region, however, can be further divided into two subregions (marked A and B). The thicker and lighter region closest to the AlSi12 (marked C) has a uniform structure with fine darker particles distributed evenly in the light matrix. Fig. $4 \mathrm{~b}$ shows a higher magnification image where the microstructure of the three regions can be seen.

Details of the bonding zone were examined using SEM/EDS. Fig. 5a shows a low magnification SEM image of the microstructure of the bonding zone and the linear distribution of elements along the marked line. As can be seen from the linear analysis, the bonding zone is mainly composed of $\mathrm{Mg}$, $\mathrm{Al}$, and $\mathrm{Si}$. The concentration of $\mathrm{Mg}$ close to the AZ91 is slightly higher than that in the area adjacent to the AlSi12.

In contrast, the concentration of $\mathrm{Al}$ increases slightly with increasing distance from the area close to the AZ91. Si was detected only in regions B and C of the bonding zone. The high magnification images in Figs. $5 b$ to d reveal details of the microstructure of the three regions (A, B and C). The EDS quantitative analysis was carried out at points 1 to 11 marked in these figures. The results are provided in Table 2. A lamellar structure is visible in the AZ91 alloy close to the bonding zone (Fig. 5b). At point 1, a high concentration of Al was detected, which suggests that during compound casting, enrichment of AZ91 with $\mathrm{Al}$ occurs locally close to the bonding zone and plate-like precipitates of the $\mathrm{Mg}_{17} \mathrm{Al}_{12}$ phase form in the solid solution of $\mathrm{Al}$ in $\mathrm{Mg}$ [34]. This phenomenon was also observed in the AZ91/A1Si12 joint fabricated using an unmodified AlSi12 insert.

Changes in the AZ91 alloy microstructure caused by the diffusion of $\mathrm{Al}$ were visible at a distance of about $200 \mu \mathrm{m}$ from the bonding zone. Fig. $5 \mathrm{~b}$ reveals that region A of the bonding zone close to the AZ91 alloy has a eutectic structure. The eutectic is composed of an $\mathrm{Mg}_{17} \mathrm{Al}_{12}$ intermetallic phase (light phase - point 

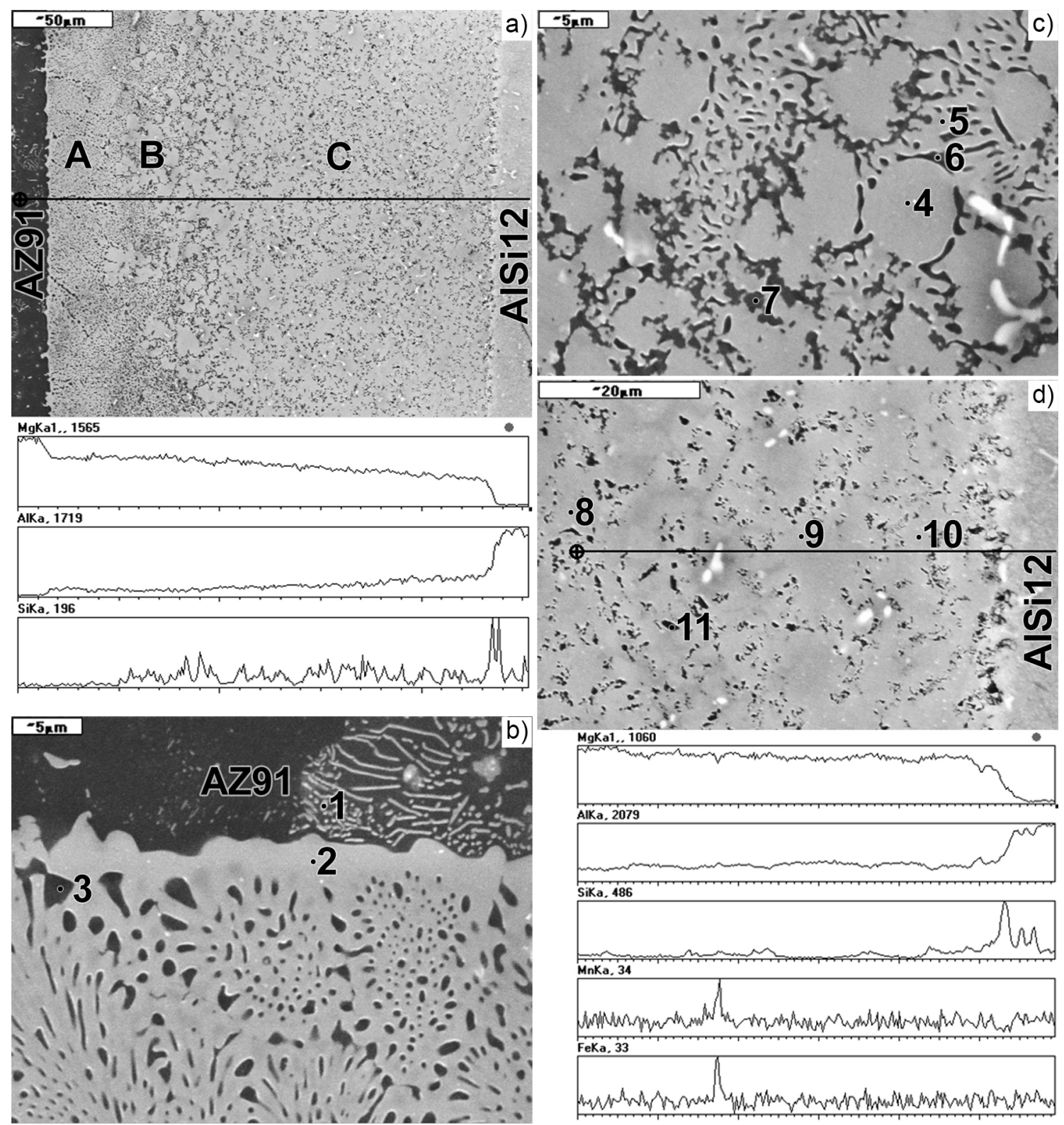

Fig. 5. SEM images of the bonding zone between AZ91 and modified AISi12; a) low magnification image with EDS line scan results; b) high magnification image of zone $A ; c)$ high magnification image of zone $B$; $d$ ) high magnification image of zone $C$ with EDS line scan results

2) and a solid solution of $\mathrm{Al}$ in $\mathrm{Mg}$ (dark phase - point 3). In region $\mathrm{B}$ (Fig. 5c), the light dendrites of the $\mathrm{Mg}_{17} \mathrm{Al}_{12}$ intermetallic phase (point 4) are surrounded by a eutectic $\left(\mathrm{Mg}_{17} \mathrm{Al}_{12}\right.$ (point 5) + a solid solution of $\mathrm{Al}$ in $\mathrm{Mg}$ (point 6)). The region also contains fine grey particles. The EDS result obtained for point 7 suggests that these particles are the $\mathrm{Mg}_{2} \mathrm{Si}$ phase. Fig. 5d shows details of the microstructure of region $\mathrm{C}$ adjacent to the AlSi12 alloy and a distribution of elements along the marked line. In this region, there are Si-rich grey particles regularly distributed in the light matrix rich in $\mathrm{Mg}$ and $\mathrm{Al}$. The EDS quantitative analysis was carried out for the light matrix at points 8 to 10 . The analysis at point 8 indicates the $\mathrm{Mg}_{17} \mathrm{Al}_{12}$ intermetallic phase. The data obtained for the region closer to the AlSi12 alloy (points 9 and 10) suggest the $\mathrm{Al}_{3} \mathrm{Mg}_{2}$ intermetallic phase. The quantitative analysis of the gray particles (point 11) indicates the $\mathrm{Mg}_{2} \mathrm{Si}$ phase. From the linear distribution of elements, it is clear that the fine, white particles found in this area are rich in $\mathrm{Al}, \mathrm{Si}, \mathrm{Mn}$ and $\mathrm{Fe}$. In the bonding zone formed between the AZ91 and the thermally modified 
Table 2. Results of the EDS quantitative analysis at points marked in Fig. 5

\begin{tabular}{ccccc}
\hline \multirow{2}{*}{ Point } & $\mathrm{Mg}$ & $\mathrm{Al}$ & $\mathrm{Zn}$ & $\mathrm{Si}$ \\
\cline { 2 - 5 } & \multicolumn{5}{c}{$[$ at.\%] } \\
\hline 1 & 85.11 & 14.77 & 0.12 & - \\
\hline 2 & 65.42 & 34.18 & 0.40 & - \\
\hline 3 & 79.76 & 20.24 & - & - \\
\hline 4 & 61.68 & 38.32 & - & - \\
\hline 5 & 63.23 & 36.77 & - & - \\
\hline 6 & 74.76 & 25.24 & - & - \\
\hline 7 & 61.18 & 5.51 & - & 33.31 \\
\hline 8 & 62.10 & 37.90 & - & - \\
\hline 9 & 40.67 & 59.33 & - & - \\
\hline 10 & 40.18 & 59.82 & - & - \\
\hline 11 & 60.27 & 5.82 & - & 33.91 \\
\hline
\end{tabular}

AlSi12, there were no cracks that could reduce the mechanical properties of the joint. Fig. 6 shows that, in this case, only single pores occurred locally in the bonding zone.

It can be assumed that the formation of the bonding zone between AZ91 and AlSi12, described

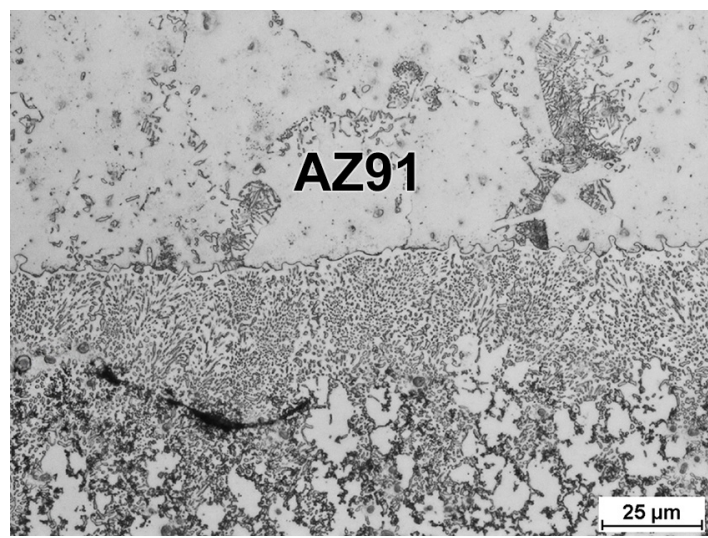

Fig. 6. An OM image of the microstructure of the AZ91/AISi12 joint with some local porosity in the bonding zone

in this study, was as follows. The compound casting process involved pouring liquid AZ91 alloy heated to $660{ }^{\circ} \mathrm{C}$ onto a solid AlSi12 alloy insert preheated to $300{ }^{\circ} \mathrm{C}$, which led to the interdiffusion of the elements at the reactive interface as well as partial melting of the AlSi12 alloy surface. A thin layer of the AlSi12 insert

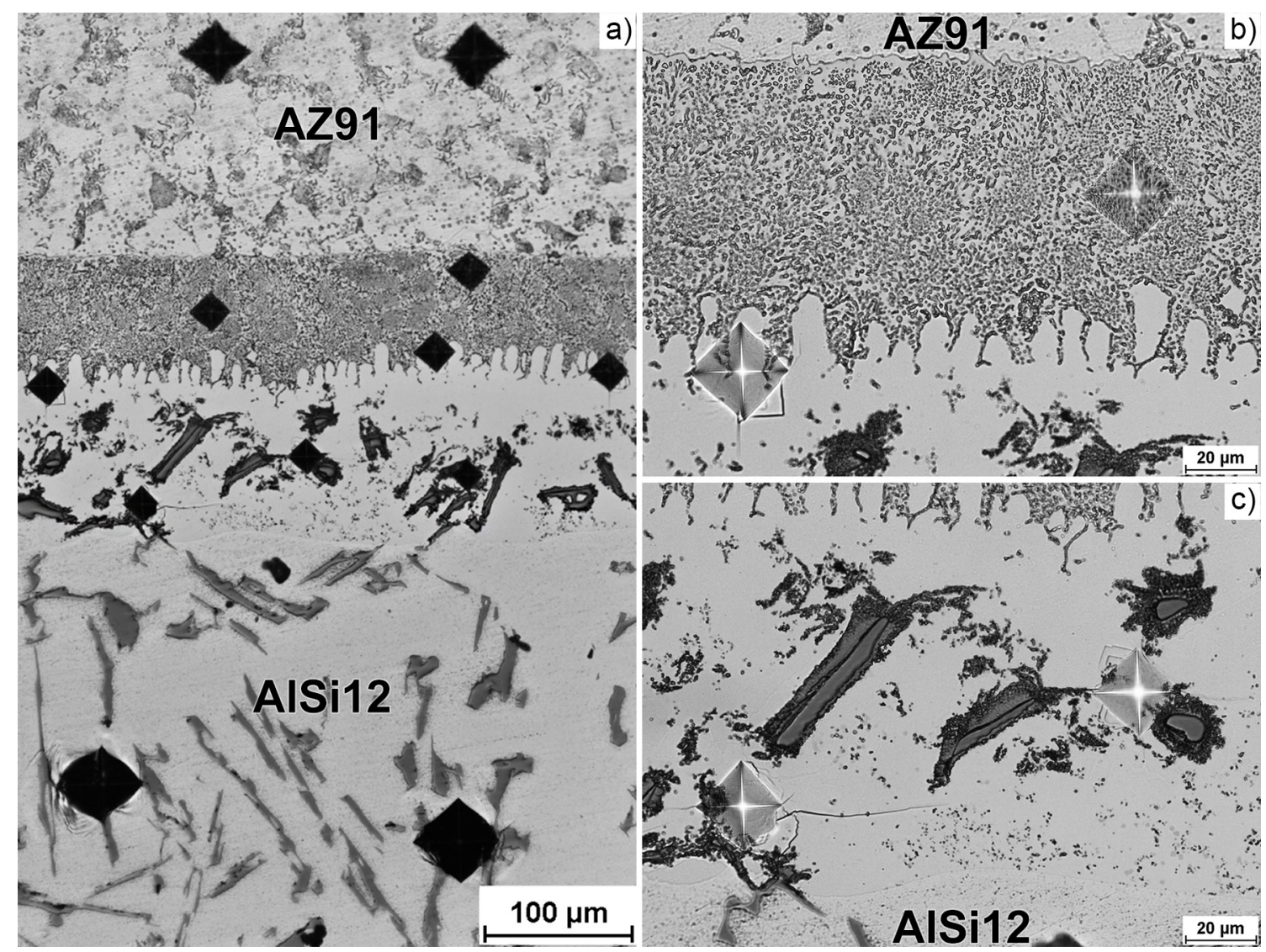

Fig. 7. Microhardness of the bonding zone of the AZ91/AISi12 joint fabricated using unmodified AlSi12; a) low magnification; b) high magnification of the area close to the AZ91; c) high magnification of the region close to the AISi12 
(100 $\mu \mathrm{m}$ to $150 \mu \mathrm{m})$ and the AZ91 alloy solidifying at the interface were mutually enriched with the elements present in the two alloys as a result of diffusion and fusion processes. When the temperature of the AZ91/ AlSi12 bimetal fell after casting, the solidified liquid formed a continuous transition zone containing $\mathrm{Mg}-\mathrm{Al}$ intermetallic phases. The microstructure of the zone was not homogeneous because of the concentration gradient in the reactive interface. Compound casting with the use of thermally modified AlSi12 aluminium alloy inserts led to the formation of a bonding zone that was more uniform in thickness and contained no cracks. In this case, the microstructure of the bonding zone close to the AlSi12 was relatively uniform. Fine $\mathrm{Mg}_{2} \mathrm{Si}$ particles were distributed evenly in the $\mathrm{Mg}-\mathrm{Al}$ intermetallic phases matrix. There were no Si particles that were not fully consumed in the reaction with $\mathrm{Mg}$ or the coarse Chinese script-like Al-Si-Mn-Fe phases.

Figs. 7 and 8 show impressions left by the Vickers indenter in the AZ91/AlSi12 joints fabricated using an unmodified and a thermally modified AlSi12 insert, respectively. Whichever the case, the microhardness of the AZ91 alloy was in the range of $56.2 \mathrm{HV}$ to 65.5 HV. The unmodified and thermally modified AlSi12 alloy inserts differed in microhardness, which was 43 $\mathrm{HV}$ to $48.5 \mathrm{HV}$ (Fig. 7) and $51.7 \mathrm{HV}$ to $53.8 \mathrm{HV}$ (Fig. 8 ), respectively. As is evident from these figures, the impressions in both bonding zones were much smaller than those in the alloys joined, which indicates the high hardness of the interface. The microhardness values were reported to change across the bonding zones because of its non-uniform microstructure. For the AZ91/A1Si12 joint produced with an unmodified AlSi12 insert (Fig. 7), the microhardness of the eutectic region close to the AZ91 alloy was ranged from 156 to $170.4 \mathrm{HV}$. Slightly higher values (171.6 $\mathrm{HV}$ to $180.5 \mathrm{HV}$ ) were reported in the transition area between the eutectic and the $\mathrm{Mg}_{17} \mathrm{Al}_{12}$ phase region, where dendrites of the $\mathrm{Mg}_{17} \mathrm{Al}_{12}$ phase were found. Higher microhardness (198.6 HV to $252.2 \mathrm{HV}$ ) was observed in the region close to the AlSi12 aluminium alloy. The values, however, varied significantly. The highest microhardness was reported in the areas where $\mathrm{Mg}_{2} \mathrm{Si}$ phase agglomerates or not fully consumed $\mathrm{Si}$
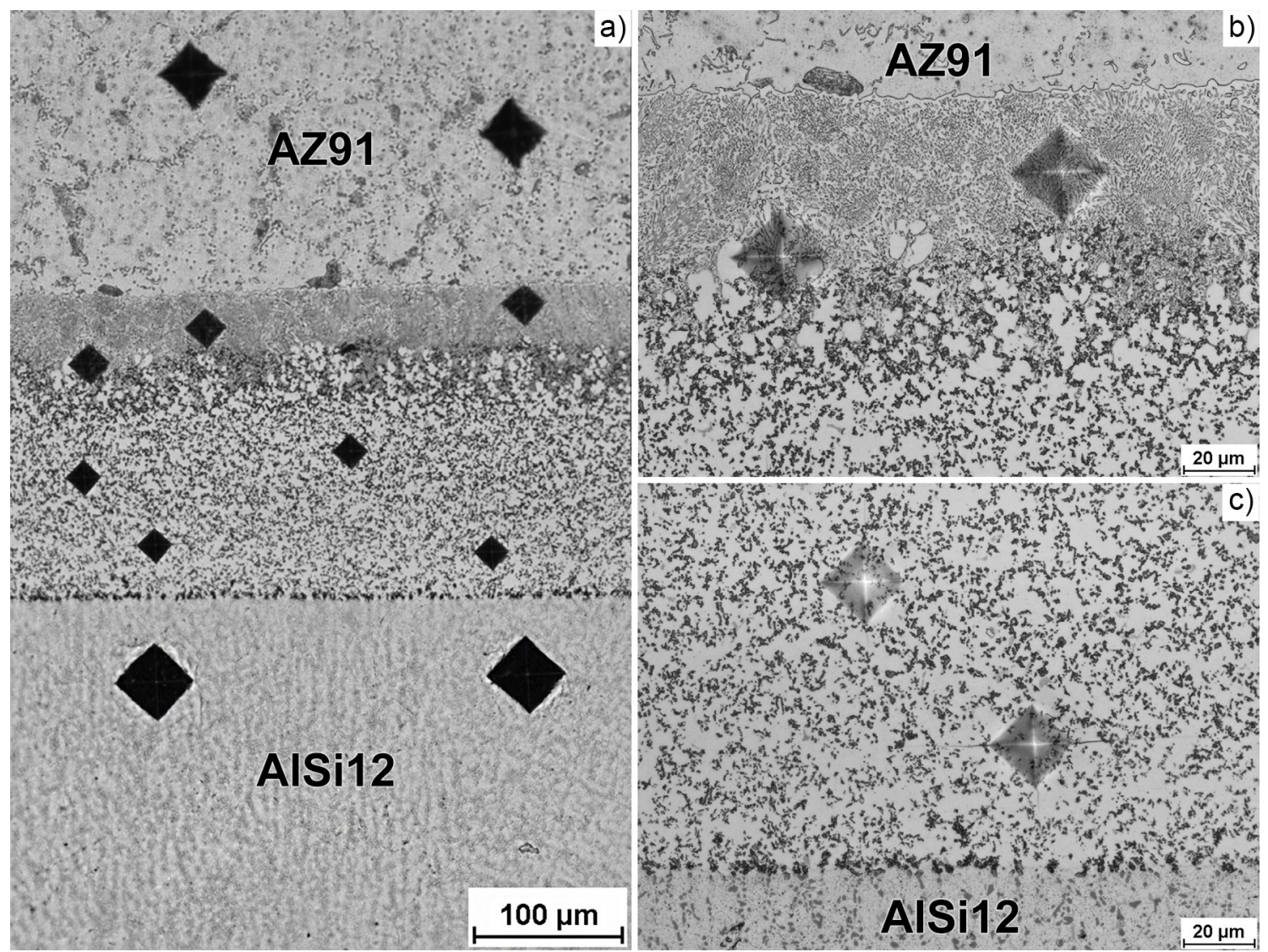

Fig. 8. Microhardness of the bonding zone of the AZ91/AISi12 joint fabricated using modified AISi12; a) low magnification; b) high magnification of the area close to the AZ91; c) high magnification of the region close to the AISi12 
particles surrounded by the $\mathrm{Mg}_{2} \mathrm{Si}$ phase occurred in the $\mathrm{Mg}-\mathrm{Al}$ intermetallic phases matrix. As can be seen from the higher magnification images in Figs. $7 \mathrm{~b}$ and c, no cracks were observed near the impressions left in the eutectic region; they developed, however, at the corners and near the edges of the impressions in the bonding zone close to the AlSi12 alloy, which suggests that the $\mathrm{Mg}-\mathrm{Al}$ intermetallic phases constituting the matrix of this region were brittle. In the bonding zone of the AZ91/AlSi12 bimetal fabricated from modified AlSi12 (Fig. 8), the microhardness of the eutectic region ranged between $158.5 \mathrm{HV}$ and $171.3 \mathrm{HV}$. The microhardness of the region close to the AlSi12 did not differ much, either (224.7 HV to $233.8 \mathrm{HV}$ ). This was a consequence of a more uniform structure of this region, which contained fine $\mathrm{Mg}_{2} \mathrm{Si}$ phase particles distributed regularly in the $\mathrm{Mg}-\mathrm{Al}$ intermetallic phases matrix. As can be seen from Fig. 8b, no cracks are propagating from the impression in the eutectic region. Cracks propagating from the impression corners (Fig. 8c) were detected only in the region adjacent to AlSi12, where $\mathrm{Mg}_{2} \mathrm{Si}$ particles were embedded in the $\mathrm{Al}_{3} \mathrm{Mg}_{2}$ intermetallic phase matrix, which indicates that this intermetallic phase had higher brittleness than the $\mathrm{Mg}_{17} \mathrm{Al}_{12}$ phase constituting the bonding zone matrix close to the eutectic region.

\section{CONCLUSIONS}

The AZ91/A1Si12 bimetallic joints under analysis were fabricated through liquid-solid compound casting. The process involved pouring liquid AZ91 magnesium alloy heated to $660^{\circ} \mathrm{C}$ onto a solid AlSi12 aluminium alloy insert placed in a steel mould, both preheated to $300{ }^{\circ} \mathrm{C}$. Two types of AlSi12 inserts were used in the experiment: unmodified and thermally modified.

It was found that the thermal modification resulted in the refinement of the AlSi12 alloy microstructure and was consequently responsible for the microstructural changes in the bonding zone.

When an unmodified insert was used, the bonding zone was non-uniform in thickness. The region closest to the AZ91 alloy had a eutectic structure $\left(\mathrm{Mg}_{17} \mathrm{Al}_{12}\right.$ + a solid solution of $\mathrm{Al}$ in $\mathrm{Mg}$ ). The region adjacent to the AlSi12 alloy was non-uniform. The Mg-Al intermetallic phases matrix contained partly reacted $\mathrm{Si}$ particles surrounded by the $\mathrm{Mg}_{2} \mathrm{Si}$ phase, single fine $\mathrm{Mg}_{2} \mathrm{Si}$ particles and their agglomerates as well as irregularly distributed coarse Al-Si-Mn-Fe phase particles. Long parallel cracks were observed in this area of the bonding zone.
In the case of the AZ91/AlSi12 joint fabricated using a thermally modified AlSi12 insert, the bonding zone was uniform in thickness, and no cracks were detected. The region of the bonding zone close to the AZ91 alloy also had a eutectic structure. Significant microstructural changes were observed in the region close to the AlSi12 alloy. The microstructure of the bonding zone adjacent to the AlSi12 was uniform. There were fine $\mathrm{Mg}_{2} \mathrm{Si}$ particles evenly distributed in the $\mathrm{Mg}$-Al intermetallic phases matrix. Fine Al-Si$\mathrm{Mn}-\mathrm{Fe}$ phase particles were also present in this zone.

It was found that, for both bimetallic joints, the microhardness of the bonding zone was several times higher than those of the alloys joined. In the AZ91/ AlSi12 joint fabricated using modified AlSi12 alloy, the microhardness values in the region close to the AlSi12 alloy did not differ significantly because of its uniform structure. This type of microstructure was less susceptible to cracking when subjected to indentation load.

\section{REFERENCES}

[1] Avci, A., Ilkaya, N., Simsir, M.M., Akdemir, A. (2009). Mechanical and microstructural properties of low-carbon steelplate-reinforced gray cast iron. Journal of Materials Processing Technology, vol. 209, no. 3, p. 1410-1416, D0l:10.1016/j. jmatprotec.2008.03.052.

[2] Tenerowicz, S., Suchoń, J., Cholewa, M. (2010). Studies of the transition zone in steel - chromium cast iron bimetallic casting. Archives of Foundry Engineering, vol. 10, no. 1, p. 199-204.

[3] Wróbel, T., Szajnar, J. (2015). Bimetallic casting: ferritic stainless steel - grey cast iron. Archives of Metallurgy and Materials, vol. 60, no. 3, p. 2361-2365, D0l:10.1515/amm2015-0385.

[4] Przyszlak, N., Wróbel, T. (2019). Self-hardening of X46Cr13 steel integrated with base from grey cast iron in bimetallic system. Archives of Foundry Engineering, vol. 19, no. 2, p. 2934, DOI:10.24425/afe.2019.127112.

[5] Xiao, X., Ye, S., Yin, W., Xue, Q. (2012). HCWCl/ carbon steel bimetal liner by liquid-liquid compound lost foam casting. Journal of Iron and Steel Research, vol. 19, no. 10, p. 13-19, DOI:10.1016/S1006-706X(12)60145-9.

[6] Wróbel, T. (2014). Characterization of bimetallic castings with an austenitic working surface layer and an unalloyed cast steel base. Journal of Materials Engineering and Performance, vol. 23, no. 5, p. 1711-1717, D0l:10.1007/s11665-0140953-4.

[7] Choe, K.H., Park, K.S., Kang, G.H., Cho, G.S., Kim, K.Y., Lee, K.W., Kim, M.H., Ikenaga, A., Koroyasu, S. (2008). Study of the interface between steel insert and aluminum casting in EPC. Journal of Materials Science \& Technology, vol. 24, no. 1, p. 60-64.

[8] Jiang, W., Li, G., Wu, Y., Liu, X., Fan, Z. (2018). Effect of heat treatment on bonding strength of aluminum/steel bimetal produced by a compound casting. Journal of Materials 
Processing Technology, vol. 258, p. 239-250, D0l:10.1016/j. jmatprotec.2018.04.006.

[9] Zare, G.R., Divandari, M., Arabi, H. (2013). Investigation on interface of $\mathrm{Al} / \mathrm{Cu}$ couples in compound casting. Materials Science and Technology, vol. 29, p. 190-196, D0l:10.1179/1 743284712 Y.0000000096.

[10] Papis, K.J.M., Hallstedt, B., Loffler, J.F., Uggowitzer, P.J. (2008). Interface formation in aluminium - aluminium compound casting. Acta Materialia, vol. 56, no. 13, p. 3036-3043, DOI:10.1016/j.actamat.2008.02.042.

[11] Sun, J., Song, X., Wang, T., Yu, Y., Sun, M., Cao, Z., Li, T. (2012). The microstructure and property of Al-Si alloy and Al-Mn alloy bimetal prepared by continuous casting. Materials Letters, vol. 67, no. 1, p. 21-23, D0l:10.1016/j.matlet.2011.08.112.

[12] Papis, K.J.M., Loffler, J.F., Uggowitzer, P.J. (2010). Interface formation between liquid and solid Mg alloys - an approach to continuously metallurgic joining of magnesium parts. Materials Science and Engineering, vol. 527, no. 9, p. 22742279, D0I:10.1016/j.msea.2009.11.066.

[13] Papis, K.J.M., Loffler, J.F., Uggowitzer, P.J. (2009). Light metal compound casting. Science in China Series E: Technological Sciences, vol. 52, p. 46-51, Dol:10.1007/s11431-008-0345-9.

[14] Hajjari, E., Divandari, M., Razavi, S.H., Emami, S.M., Homma, T., Kamado, S. (2011). Dissimilar joining of Al/Mg light metals by compound casting process. Journal of Materials Science, vol. 46, p. 6491-6499, D0l:10.1007/s11431-008-0345-9.

[15] Hajjari, E., Divandari, M., Razavi, S.H., Homma, T., Kamado, S. (2012). Microstructure characteristics and mechanical properties of Al 413/Mg joint in compound casting process. Metallurgical and Materials Transactions A, vol. 43, no. 12, p. 4667-4677, D0l:10.1007/s11661-012-1296-0.

[16] Guler, K.A., Kisasoz, A., Karaaslan, A. (2014). Fabrication of $\mathrm{Al} / \mathrm{Mg}$ bimetal compound casting by lost foam technique and liquid-solid process. Materials Testing, vol. 56, no. 9, p. 700702, DOI:10.3139/120.110624.

[17] Mola, R., Bucki, T., Dziadoń, A. (2016). Formation of Alalloyed layer on magnesium with use of casting techniques. Archives of Foundry Engineering, vol. 16, no. 1, p. 112-116, DOI:10.1515/afe-2016-0013.

[18] Li, G., Jiang, W., Fan, Z., Jiang, Z., Liu, X., Liu, F. (2017). Effects of pouring temperature on microstructure, mechanical properties, and fracture behavior of $\mathrm{Al} / \mathrm{Mg}$ bimetallic composites produced by lost foam casting process. The International Journal of Advanced Manufacturing Technology, vol. 91, no. 1-4, p. 1355-1368, D0l:10.1007/s00170-0169810-y.

[19] Mola, R., Bucki, T., Dziadoń, A. (2017). Effects of the pouring temperature on the formation of the bonding zone between AZ91 and AlSi17 in the compound casting process. IOP Conference Series: Materials Science and Engineering, vol. 179, no. 1, p. 1-6, D0I:10.1088/1757-899X/179/1/012053.

[20] Mola, R., Bucki, T. (2018). The microstructure and properties of the bimetallic AZ91/AISi17 joint produced by compound casting. Archives of Foundry Engineering, vol. 18, no. 1, p. 7176, D0I:10.1515/afe-2017-0036.

[21] Mola, R., Bucki, T. (2018). Characterization of the bonding zone in a ZE41/AISi12 joint fabricated by liquid-solid compound casting. Archives of Foundry Engineering, vol. 18, no. 2, p. 203-208, DOI:10.24425/122529.

[22] Jiang, Z., Fan, Z., Jiang, W., Li, G., Wu, Y., Guan, F., Jiang, H. (2018). Interfacial microstructures and mechanical properties of $\mathrm{Mg} / \mathrm{Al}$ bimetal produced by a novel liquid-liquid compound casting process. Journal of Materials Processing Technology, vol. 261, p. 149-158, D0I:10.1016/J.jmatprotec.2018.06.013.

[23] Schneider, K., McKay, B.J., Nadendla, B. (2018). Influence of zinc on intermetallic phase selection in Al-Mg compound castings. Proceedings of the $16^{\text {th }}$ International Aluminium Alloys Conference (ICAA16), p. 1-8.

[24] Liu, N., Chen, L., Fu, Y., Zhang, Y., Tan, T., Yin, F., Liang, C. (2019). Interfacial characteristic of multi-pass caliberrolled Mg/Al compound castings. Journal of Materials Processing Technology, vol. 267, p. 196-204, D0l:10.1016/j. jmatprotec.2018.12.020.

[25] Li, G., Yang, W., Jiang, W., Guan, F., Jiang, H., Wu, Y., Fan, Z. (2019). The role of vacuum degree in the bonding of $\mathrm{Al} / \mathrm{Mg}$ bimetal prepared by a compound casting process. Journal of Materials Processing Technology, vol. 265, p. 112-121, DOI:10.1016/J.jmatprotec.2018.10.010.

[26] Mola, R., Bucki, T., Gwoździk, M. (2019). The Effect of a zinc interlayer on the microstructure and mechanical properties of a magnesium alloy (AZ31)-aluminum alloy (6060) joint produced by liquid-solid compound casting. JOM, vol. 71, no. 6, p. 2078-2086, D0l:10.1007/s11837-019-03405-y.

[27] Li, G., Jiang, W., Guan, F., Zhu, J., Yu, Y., Fan, Z. (2020). Effect of different $\mathrm{Ni}$ interlayers on interfacial microstructure and bonding properties of $\mathrm{Al} / \mathrm{Mg}$ bimetal using a novel compound casting. Journal of Manufacturing Processes, vol. 50, p. 614628, D0I:10.1016/J.jmapro.2020.01.017.

[28] Abdulrahaman, S.A., Wu, Y., Gong, H., Liu, L. (2019). Determination of the effect of cold working compression on residual stress reduction in quenched aluminium alloy 2219 block. Strojniški vestnik - Journal of Mechanical Engineering, vol. 65, no. 5, p. 311-318, D0l:10.5545/sv-jme.2018.5938.

[29] Žagar, S., Šturm, R. (2019). Influence of grinding on residual stress measurements of shot peened aluminium alloy AA7075. Strojniški vestnik - Journal of Mechanical Engineering, vol. 65, no. 7-8, p. 401-409, D0l:10.5545/sv-jme.2019.6083.

[30] Fentahun, M.A., Savaş, M.A. (2018). Materials used in automotive manufacture and material selection using Ashby charts. International Journal of Materials Engineering, vol. 8, no. 3, p. 40-54, D0I:10.5923/j.ijme.20180803.02.

[31] Liu, L., Ren, D., Liu, F. (2014). A review of dissimilar welding techniques for magnesium alloys to aluminum alloys. Materials, vol. 7 , no. 5, p. 3735-3757, D0l:10.3390/ ma7053735.

[32] Okamoto, H. (1998). Al-Mg (aluminum-magnesium). Journal of Phase Equilibria, vol. 19, p. 598, DOl:10.1361/105497198770341815.

[33] Okamoto, H. (2007). Mg-Si (magnesium-silicon). Journal of Phase Equilibria and Diffusion, vol. 28, p. 229-230, D0l:10.1007/s11669-007-9038-5.

[34] Braszczyńska-Malik, K.N., Zyska, A. (2010). Influence of solidification rate on microstructure of gravity cast AZ91 magnesium alloy. Archives of Foundry Engineering, vol. 10, no. 1, p. 23-26. 